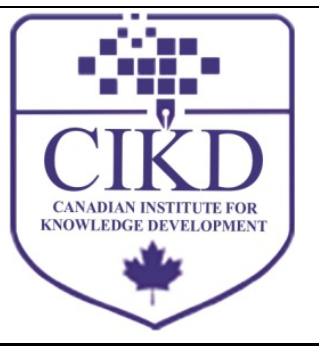

\title{
Hotel Recruitment and Selection Practices: The Case of the Greek Hotel Industry
}

\author{
Alexandra-Paraskevi Chytiri ${ }^{1}$, Fragkiskos Filippaios ${ }^{2}$, Leonidas Chytiris ${ }^{3 *}$ \\ ${ }^{1}$ Lecturer, De Montfort University, UK \\ ${ }^{2}$ Senior Lecturer, University of Kent, UK \\ ${ }^{3}$ Professor, Piraeus University, Greece
}

\begin{abstract}
Keywords:

Human Resource

Management, Practices,

Recruitment and Selection,

Hospitality, Hotel Industry,

Four and Five Star Hotels,

Greece

\section{Received}

16 May 2018

Received in revised form

27 September 2018

Accepted

30 September 2018

Correspondence:

leon@unipi.gr

Hotel industry, as a service industry, is greatly dependent upon its employees. Recruitment and Selection practices constitute an important starting stage for hotels towards generating an efficient and productive workforce. The present study, by focusing on $5^{*}$ and $4 *$ hotels, examines the current trends in the implementation and effectiveness of recruitment and selection practices in the Greek hotel industry, controlling for class category, size and ownership. An inferential quantitative research design was used, and an online survey was conducted, using a seven-point questionnaire. The study concludes that hotel industry, at least in Greece, is still using old - fashioned and cost effective recruitment and selection methods. Findings also outline that $5^{*}$ and $4 *$ hotels do not differentiate their mix of methods used in recruiting and selecting future employees. Internal recruitment methods are mostly considered to be effective in contrast to external recruitment methods. While interviews and reference checks are listed at the top of the effectiveness list of selection methods. The findings of this research enhance industry understanding of the use and effectiveness of recruitment and selection methods and indicate the need for hotels of superior class to re-examine their recruitment and selection methods and adopt more contemporary ones in their mix.
\end{abstract}

C)AIMI Journals

Most of the research in Human Resource Management has been carried out in manufacturing and commercial sector and much less in the services sector and in the hotel industry (Chand \& Katou, 2007; Hoque, 1999). Hotel industry, as a labour intensive industry, is greatly affected by 
the quality (both technical and behavioural aspects of quality) of its employees, in meeting its business goals, offering high - quality services and creating competitive advantage.

The specific characteristics of hotel industry such as high turnover, skill shortages, flexible employment patterns, low wages, heterogeneity in firm size, ownership (MNEs VS. National firms) and service class/ category make the management of human resources more crucial, in relation to specific context, for the achievement of the organisational goals (Baum, 2007; Chand \& Katou, 2007; Darvishmotevali, Arasli, Kilic, 2017; Young-Thelin \& Baluk, 2012). Attracting and selecting the right people is the starting point to the achievement of these goals by managing effectively the organisational workforce.

The aim of this research is to explore the recruiting and selection practices/methods used in the Greek hotel industry, as well as their effectiveness. The study aims to explore the differences in the mix of recruitment and selection methods implemented, between local and foreign hotels, $4^{*}$ and $5^{*}$ and of different size hotels. In addition, the findings are expected to contribute in filling the gap in HRM literature, about the recruitment and selection practices implemented in the specific context of hotel industry.

\section{Literature Review}

In an era characterized by continuous changes in the economic, political and social environment, in the era of globalization, technological advances and easy mobility of resources, firms have to compete and remain successful in this extended global arena. Therefore, there is a need for differentiation leading to a sustainable competitive advantage (Katou, 2008). In response to this need the focus has moved away from the traditionally sources (capital, land, technology) to business systems and processes and in particular to human capital, that has emerged as the new source for competitive advantage. Human resources (HR) as skills, knowledge, attitudes and competencies and the way they are managed are key factors to produce a sustainable competitive advantage, as they are hard to be imitated (Armstrong, 2017; Torrington, Hall, Taylor, Atkinson, 2017; Noe, Hollenbeck, Gerhart, \& Wright, 2015).

This is particular true for services industries, which are heavily based on human capital for their successful operation and delivery of services (Hoque, 2013). 'Travel and tourism' form one of the services' sector industries, which compared to other services industries, is characterized by continuous growth the last 70 years, even during unstable situations and crisis periods (Davidson \& Wang, 2011; Hazra \& Nemes, 2013; Ladkin, 2011). According to the World Travel and Tourism Council (2017), tourism generates 1 in 10 jobs in global economy, while in Greece the total contribution to employment is almost 30\% (Greek Tourism Organization, 2017). Hence, human resources and their management are at the heart of the business (Suh West, Shin, 2012). However, this issue is a relatively neglected issue in literature and specifically in hotel sector (Hoque, 1999; Hoque, 2013; Philippakos, 2009).

Hotel industry all over the world and particularly in Greece has several distinct characteristics, such as: heterogeneity (having large MNEs and small national hotels operating in the same region), sensitivity in changes (innovation, technological advances, economic, social and mobility issues), seasonality, human resource flexibility, high percentage of part time and non-professional employees, skill shortages, as well as low paid work, law status (for most jobs), weak power of trade unions and high level of employee turnover (Baum, 2007; Janes \& Wisnom, 2010). These characteristics imply the necessity for empirical research about 
the implementation and effectiveness of distinctive and diverse HR practices for a hotel firm to remain successful and achieve its goals, particularly, when talent shortfall remains one of the tourism industry's most pressing human resource management issues (Altin, Koseoglu, Xiaojuan, \& Riasi, 2018; Duncan, Scott, Baum, 2013; Hoque, 2013; Ubeda-Garcia, ClaverCortes, Marco-Lajara, \& Zaragoza-Saez, 2017; Mooney, Harris, \& Ryan, 2016; Nieves \& Quintana, 2016; Solnet, Kralj, \& Baum, 2015; Young-Thelin \& Boluk, 2012).

Considering Human Resource Management (HRM) as a system (inputs-process-outputs) recruitment and selection are of the most important processes for obtaining and retaining qualified employees, at a reasonable cost, and achieve person-job and organization fit (Broughton, Foley, Ledermaier, \& Cox, 2013; Chan \& Kuok, 2011; Gonzalez \& Rivres, 2017; Roth, Bobko, Van Iddekinge, \& Thatcher 2016; Stone, Deadrick, Lucaszewski, \& Johnson, 2015; Taylor, 2014). Recruitment is a set of practices/ methods taken up by the firm in order to identify and attract potential employees, while selection is also a set of practices/methods for deciding according to pre - set criteria which applicants to be appointed to jobs (Armstrong, 2017; Torrington et al., 2017). These practices are considered to be rather significant in the HRM function, as they affect all organizational practices and decisions (Chanda, Bansal, \& Chanda, 2010; Guest, 2011).

According to the systems view in HRM, HR practices are intertwined in a way that the successful or unsuccessful execution of the one has an immediate effect on the efficiency and effectiveness of the other (Guest, 2011; Huselid, 1995; Purcell, Kinnie, Hutchinson, Rayton, \& Swart, 2003; Stavrou, Brewster, \& Charalambous, 2010). For instance, if during the selection process the most qualified applicants for specific job positions are selected there will be low need for long induction (initial training). On the contrary, if a business systematically trains and provides high development programs for its employees then the poor selection and recruitment process is compensated (Torrington et al., 2017).

Focusing now in Greece, in recent years, the number of Greek firms applying the principles and methods of HRM is steadily increasing, although the greater portion of them are still using old fashioned systems and practices of HRM (Apospori, Nikandrou, Brewster, \& Papalexandris, 2008; Chytiri, 2015; Katou, 2008; Panayotopoulou, Vakola, \& Galanaki, 2007; Papalexandris \& Stavrou, 2004; Stavrou-Costea \& Papalexandris, 2015; Stavroulakis, 2009).

As far as recruitment and selection practices are concerned, MNEs operating in Greece and national/local firms tend to use mostly similar practices. The main difference that appears between the two is that MNEs tend to have written and formalised recruitment and selection practices compared to local firms. The internal sources (promotion transfer, internal posting/ehome page), recruitment through agencies, press advertisement and employee referrals are mostly used as recruitment practices, in Greece. The small/family size of Greek firms $(>85 \%$ of them are of small-medium size) justifies the extended use of employee referrals as recruitment method (Chytiri, 2015; Eleftheriou \& Robertson, 1999; Stavrou-Costea \& Papalexandris, 2015; Myloni, Harzing, \& Mirza, 2004).

Contrary to the majority of MNEs, for most Greek companies the selection process is usually not standardised and the decision is based on personal relations and subjective criteria. Interviews, resumes and references checks, application forms and word of mouth/ recommendations, are preferred as valid methods for predicting employee fit, work behaviour and performance (Nikolaou \& Judge, 2007). Group selection methods and especially group 
interviews, psychometric/personality tests and assessment centres are not often used, along with personality tests (Chytiri, 2015; Eleftheriou \& Robertson, 1999; Stavrou-Costea \& Papalexandris, 2015; Myloni, 2003). The nationality of the general manager in subsidiaries in Greece seems to play an important role in selection practices transfer from the parent company, while when the CEO has a Greek nationality, the transfer of practices is hindered (Katou \& Budhwar, 2012; Myloni, 2002).

Considering now the more recent developments in recruitment and selection, the e-methods (recruitment and selection through internet and social media), Greek firms lag behind MNEs, mostly because of their size and the level of technology applied in them (Panayotopoulou et al., 2007).

Human Resource practices in hospitality industry are underdeveloped compared to other industries (Kusluvan, Kusluvan, Ihan, \& Buyruk, 2010). This is also true for Greece where little research has been carried out up to now in the hotel sector, about HR practices and no research particularly about recruitment and selection practices, in hotels of $5^{*}$ and $4 *$ (super and high class categories).

Human Resource Management theory and research findings, overall and in hospitality industry in particular, suggest that firm's characteristics such as age, size, type of ownership, organizational structure, affect HR practices. Hotel industry specifically has neglected its Human Resources, and as a result the methods used by many hotels do not meet the goal of attracting and retaining the best possible talent (although employee attraction and retention is one of the industry's great concerns). Not surprisingly, as they use old - fashioned HR practices, they find it difficult to hire skilled and reliable staff (Bagri, Babu, \& Kukreti, 2010; Baum, 2007; Boluk, 2012; Centinel, Yolal, \& Emeksiz, 2008; Chan \& Kuok, 2011; Davidson \& Wang, 2011; Enz, 2009; McGunnigle \& Jameson, 2000; Myloni, 2002; Paraskevas, 2000; Young-Thelin \& Walsh, Enz, \& Siguaw, 2007). According to literature, hotels with high star $\left(^{*}\right)$ rating are more likely to have established formal and written HRM practices and thus, recruitment and selection practices, as well (Lockyer \& Scholarios, 2004; Paraskevas, 2000).

\section{The Study}

Based on the above literature, the aim of this research is two-fold: (a) to explore and present the current trends in recruitment and selection in Greek and foreign hotels operating in Greece, and (b) to examine the effectiveness of the relative methods used. To aid to the attainment of the first aim the following hypotheses were developed:

$\mathbf{H}_{1}$ : Hotels characteristics, such as star $\left(^{*}\right)$ category and size have an impact on the mix of recruitment and selection practices implemented.

$\mathbf{H}_{1 \mathbf{a}}$ ): Recruitment and selection practices used by $5^{*}$ hotels appear to be more diverse than those used in $4 *$ hotels.

$\mathbf{H}_{1 \mathbf{b}}$ ): Larger hotels (in number of employees) implement a more diverse mix of recruitment and selection practices and they usually use this mix for internal recruitment.

$\mathbf{H}_{2}$ : The type of ownership differentiates the recruitment and selection practices mix (MNEs/foreign hotels VS Greek hotels).

For the attainment of the second aim regarding the effectiveness of recruitment and selection methods used in hotels operating in Greece, descriptive statistics were used. 


\section{Methodology}

\section{Research Design and Questionnaire}

To meet the objectives of the study, and based on its nature, an inferential survey research design (building hypotheses first and then draw conclusions from data analysis) was employed (Diaz de Rada \& Dominguez-Alvarez, 2013; Gravlee, Bernard, Maxwell, \& Jacobsohn, 2013; Rea \& Parker, 2014). In the present study, since the aim is simply to identify and measure which, to what extend and how effectively HR practices are implemented by $4^{*}$ and $5^{*}$ hotels, in Greece, an empirical quantitative research approach is preferred. Moreover, based on the review of the relative literature, it appears that the vast majority of comparative studies in hospitality area, were conducted using quantitative research designs (mostly questionnaires and surveys) rather than qualitative ones (case studies and detailed interviews) (Aycan et al., 2000). For this reason, and taking into consideration time and geographical constraints, a quantitative research method was used-a web-based survey-so as to reach participants for data collection (Easterby-Smith, Thorpe, Jackson, \& Lowe 2008; Hayslett \& Wildemuth, 2004; Wright, 2005). The research instrument used to collect data was a questionnaire designed as a combination of the questionnaires used in the studies of a) Lockyer \& Scholarios (2004) on hotel staff selection practices, b) Paraskevas (2000) on management selection practices in Greek hospitality industry, and of c) Lievens, Van Dam, and Anderson (2002) on personnel selection trends. Therefore, any issues of validity and reliability of the present questionnaire items have already been addressed in these past studies. The web-based (in English language) seven-point scale questionnaire was e-mailed to participants-Human Resource Managers or Hotel Managers responsible for managing employees.

\section{Sample Selection and Data Analysis Methods}

The prefecture of Attica, where the capital city of Greece, Athens is, was decided to be the sample area because most of its hotels operate all year around, so not really affected by seasonality, while a great number of $5^{*}$ and $4^{*}$ hotels also operate in it. The official list of the $5^{*}$ and $4 *$ star hotels was provided by the Greek Tourism Organisation (GTO) and the Hellenic Chamber of Hotels. This provided us with a sample comprised of, 34 five-star $\left(5^{*}\right)$ hotels and 92 four-star $\left(4^{*}\right)$ hotels. From those 126 hotels, 8 were not operating all year round and thus they were excluded from the sample. Thus, 118 hotels in total were surveyed. Regarding the nationality, 15 were international brands (MNEs) and the rest local/national brands. From all of those conducted to participate in the survey, 33 responded which gives an almost $28 \%$ response rate. This rate is representative and high for the Greek hotel industry according to Paraskevas (2000) as well as for organizational surveys. For the analysis of the data, descriptive statistics, cross-tabulations (comparisons) and hypotheses testing (T-test, at a $=5 \%$ significance level) have been conducted, by using the STATA software package.

\section{Results}

The profile of the 33 hotels participated in this study is shown in Table 1. A percentage of 88 of hotels were of Greek ownership, 36\% were $5 *$ hotels and $70 \%$ employed more than 200 employees. 
Table 1

Profile of the Hotels $(n=33)$

\begin{tabular}{lccc}
\hline Ownership & Percentage & Star Category & Percentage \\
\hline Greek & $88 \%$ & $5 *($ stars $)$ & $36 \%$ \\
Foreign/ Subsidiary & $12 \%$ & $4 *($ stars $)$ & $64 \%$ \\
\hline Size & Percentage & & \\
\hline$\leq 200$ employees & $70 \%$ & & \\
$>200$ employees & $30 \%$ & & \\
\hline
\end{tabular}

\section{Recruitment and Selection Practices in 5* and 4*hotels (H1a)}

The analysis of data suggests that almost none of the recruitment and selection methods is highly often used by hotels, either $4^{*}$ or $5^{*}$, as their means in 7-point Likert scale range from 2.5 up to 4.5 . In addition, it can be observed that mean scores for $5^{*}$ hotels are in their majority higher, implying that $5^{*}$ hotels have more established recruitment and selection practices compared to $4 *$ hotels. However, none of the tests yield statistically significant results regarding the mean and standard deviation differences (Table 2). Therefore, according to t-test H1a is rejected, meaning that there are no significant differences between $4^{*}$ and $5^{*}$ star hotels in Attica.

Table 2

Hotel Category VS Recruitment Methods

\begin{tabular}{|c|c|c|c|}
\hline Recruitment Methods & Star Category & $M$ & $t(\mathrm{a}=5 \%)$ \\
\hline Promotion & $\begin{array}{l}4^{*} \\
5^{*}\end{array}$ & $\begin{array}{l}3.66 \\
4.47\end{array}$ & -1.32 \\
\hline Transfer & $\begin{array}{l}4^{*} \\
5^{*}\end{array}$ & $\begin{array}{c}2.5 \\
4.42\end{array}$ & -3.31 \\
\hline Job Rotation & $\begin{array}{l}4^{*} \\
5^{*}\end{array}$ & $\begin{array}{c}3.5 \\
4.28\end{array}$ & -1.47 \\
\hline Agencies & $\begin{array}{l}4^{*} \\
5^{*}\end{array}$ & $\begin{array}{c}2.5 \\
2.52\end{array}$ & -.03 \\
\hline Liaison with universities & $\begin{array}{l}4^{*} \\
5^{*}\end{array}$ & $\begin{array}{l}3.66 \\
3.28\end{array}$ & .51 \\
\hline Job fairs* & $\begin{array}{l}4^{*} \\
5^{*}\end{array}$ & $\begin{array}{l}2.66 \\
2.38\end{array}$ & .51 \\
\hline Walk ins, unsolicited resumes & $\begin{array}{l}4^{*} \\
5^{*}\end{array}$ & $\begin{array}{l}3.16 \\
3.85\end{array}$ & -1.04 \\
\hline Employee referrals & $\begin{array}{l}4^{*} \\
5^{*}\end{array}$ & $\begin{array}{l}3.91 \\
4.42\end{array}$ & -1.03 \\
\hline Company website & $\begin{array}{l}4^{*} \\
5^{*}\end{array}$ & $\begin{array}{l}4.08 \\
2.95\end{array}$ & 1.36 \\
\hline Internet/Social Media & $\begin{array}{l}4^{*} \\
5^{*}\end{array}$ & $\begin{array}{l}3.25 \\
2.80\end{array}$ & .65 \\
\hline Print Advertisement & $\begin{array}{l}4^{*} \\
5^{*}\end{array}$ & $\begin{array}{l}3.58 \\
2.85\end{array}$ & .93 \\
\hline Internal job posting & $\begin{array}{l}4^{*} \\
5^{*}\end{array}$ & $\begin{array}{l}3.58 \\
4.52\end{array}$ & -1.29 \\
\hline Other & $\begin{array}{l}4^{*} \\
5^{*}\end{array}$ & $\begin{array}{l}1.66 \\
1.76\end{array}$ & -.16 \\
\hline
\end{tabular}

The second part of H1a refers to the diversity in implementation of selection practices mix. According to Table 3, t-test is significant for applications forms and resume screening. This means that there are differences among $4 *$ and $5 *$ hotels concerning these two practices and thus only for them H1a is accepted. 
Table 3

Hotel Category VS Selection Methods

\begin{tabular}{|c|c|c|c|}
\hline Selection Practices & Star Category & $M$ & $t(\mathrm{a}=5 \%)$ \\
\hline \multirow[b]{2}{*}{ Reference checks } & $4^{*}$ & 5.333333 & -1.3964 \\
\hline & $5^{*}$ & 6.095238 & \\
\hline \multirow{3}{*}{ Application forms } & $4^{*}$ & 4.5 & $-3.2778 *$ \\
\hline & $5 *$ & 6.380952 & \\
\hline & $4 *$ & 4.833333 & $-3.2564 *$ \\
\hline Resume screening & $5 *$ & 6.428571 & \\
\hline \multirow{3}{*}{ Knowledge Tests } & $4 *$ & 3.083333 & -0.9200 \\
\hline & $5 *$ & 3.857143 & \\
\hline & $4^{*}$ & 4.5 & 1.5526 \\
\hline \multirow[t]{2}{*}{ Performance/Work sample tests } & $5^{*}$ & 3.333333 & \\
\hline & $4 *$ & 2.333333 & -0.5721 \\
\hline \multirow[t]{2}{*}{ Ability tests } & $5 *$ & 2.714286 & \\
\hline & $4 *$ & 2.75 & -0.0173 \\
\hline \multirow[t]{2}{*}{ Motivational inventories } & $5 *$ & 2.761905 & \\
\hline & $4 *$ & 2.666667 & -0.8284 \\
\hline \multirow[t]{2}{*}{ Personality inventories } & $5 *$ & 3.333333 & \\
\hline & $4 *$ & 2.666667 & 0.0000 \\
\hline Integrity tests & $5 *$ & 2.666667 & \\
\hline \multirow[t]{2}{*}{ Interviews } & $4 *$ & 6.333333 & -0.5298 \\
\hline & $5 *$ & 6.571429 & \\
\hline \multirow{3}{*}{ Assessment centers } & $4 *$ & 2.166667 & 1.0268 \\
\hline & $5 *$ & 1.714286 & \\
\hline & $4 *$ & 2.583333 & 1.7084 \\
\hline \multirow[t]{2}{*}{ Social media } & $5 *$ & 1.761905 & \\
\hline & $4 *$ & 1.75 & 0.6899 \\
\hline Other & $5 *$ & 1.428571 & \\
\hline
\end{tabular}

\section{Recruitment and Selection Practices in Greek vs Foreign Subsidiaries (hotels) (H2)}

Regarding the recruitment practices used by both Greek and foreign hotel firms, these rarely include the use of recruitment agencies, as it can be seen from the mean scores (Table 4). Internal recruitment methods such as promotion and transfer of employees, the level of use in Greek hotels varies from never to always, while foreign subsidiaries tend to use them slightly more frequently. E-recruitment and selection methods (internet, social media and company website) are much more used by MNEs/foreign hotels leaving Greek hotels behind (Table 4). This is mainly because technological development in Greece has not reached a high point yet (Table 4). Job fairs, although not often used by both foreign and Greek hotels, it is statistically significant between the two - it is more used by foreign hotels. This can be explained by the assumption that foreign hotels can afford the relative expenses.

A statistically significant difference appears to exist between the two types of owners, regarding the internal job posting recruitment method. MNEs subsidiaries make much use of this method, compared to Greek ones.

As far as the selection tools mix is concerned it can be seen from Table 5 that t-test for knowledge tests appears to be significant. Consequently, all the other relations appear to be non-significant, leaving little space for differences in selections methods used either by Greek or foreign hotels, and rendering $\mathrm{H} 2$ for this part as non-true/verified. Again as in the previous section where, selection methods were compared with hotel star category, the same selection tools are preferred by both Greek and foreign hotels highly - these being reference checks, resume screening and interviews. All of them are slightly more used by foreign companies. It should also be mentioned that interviews are always used by MNEs and integrity test are also often used. 
Table 4

Recruitment methods vs Ownership (nationality)

\begin{tabular}{|c|c|c|c|}
\hline Recruitment methods & Ownership (Nationality) & Mean & t-test $(a=5 \%)$ \\
\hline \multirow{2}{*}{ Promotion } & Greek & 4.03 & \multirow{2}{*}{-1.35} \\
\hline & Foreign/Subsidiary & 5.25 & \\
\hline \multirow{2}{*}{ Transfer } & Greek & 3.62 & \multirow{2}{*}{-.89} \\
\hline & Foreign/Subsidiary & 4.5 & \\
\hline \multirow{2}{*}{ Job Rotation } & Greek & 4.06 & \multirow{2}{*}{.70} \\
\hline & Foreign/Subsidiary & 3.5 & \\
\hline \multirow{2}{*}{ Agencies } & Greek & 2.48 & \multirow{2}{*}{-.26} \\
\hline & Foreign/Subsidiary & 2.75 & \\
\hline \multirow{2}{*}{ Liaison with universities } & Greek & 3.31 & \multirow{2}{*}{-.87} \\
\hline & Foreign/Subsidiary & 4.25 & \\
\hline \multirow{2}{*}{ Job fairs } & Greek & 2.31 & \multirow{2}{*}{$-1.83 *$} \\
\hline & Foreign/Subsidiary & 3.75 & \\
\hline \multirow{2}{*}{ Walk ins, unsolicited resumes } & Greek & 3.48 & \multirow{2}{*}{-1.04} \\
\hline & Foreign/Subsidiary & 4.5 & \\
\hline \multirow{2}{*}{ Employee referrals } & Greek & 4.20 & \multirow{2}{*}{-.39} \\
\hline & Foreign/Subsidiary & 4.5 & \\
\hline \multirow{2}{*}{ Company website } & Greek & 3.10 & \multirow{2}{*}{$-1.79 *$} \\
\hline & Foreign/Subsidiary & 5.25 & \\
\hline \multirow{2}{*}{ Internet/Social Media } & Greek & 2.65 & \multirow{2}{*}{$-2.96 *$} \\
\hline & Foreign/Subsidiary & 5.25 & \\
\hline \multirow[b]{2}{*}{ Print Advertisement } & Greek & 2.93 & \multirow[t]{2}{*}{-1.40} \\
\hline & Foreign/Su4sidiary & 4.5 & \\
\hline \multirow{2}{*}{ Internal job posting } & Greek & 3.89 & \multirow{2}{*}{$-2.32 *$} \\
\hline & Foreign/Subsidiary & 6.25 & \\
\hline \multirow{2}{*}{ Other } & Greek & 1.58 & \multirow{2}{*}{-1.39} \\
\hline & Foreign/Subsidiary & 2.75 & \\
\hline
\end{tabular}

Table 5

Selection Methods VS Ownership (nationality)

\begin{tabular}{|c|c|c|c|}
\hline Selection Practices & Ownership (Nationality) & Mean & t-test $(\mathrm{a}=5 \%)$ \\
\hline \multirow{2}{*}{ Reference checks } & Greek & 5.68 & \multirow{2}{*}{-1.31} \\
\hline & Foreign/Subsidiary & 6.75 & \\
\hline \multirow{2}{*}{ Application forms } & Greek & 5.51 & \multirow{2}{*}{-1.56} \\
\hline & Foreign/Subsidiary & 4 & \\
\hline \multirow{2}{*}{ Resume screening } & Greek & 5.79 & \multirow{2}{*}{-.54} \\
\hline & Foreign/Subsidiary & 6.25 & \\
\hline \multirow{2}{*}{ Knowledge Tests } & Greek & 3.31 & \multirow{2}{*}{$-1.83 *$} \\
\hline & Foreign/Subsidiary & 5.5 & \\
\hline \multirow{2}{*}{ Performance/Work sample tests } & Greek & 3.96 & \multirow{2}{*}{1.54} \\
\hline & Foreign/Subsidiary & 2.25 & \\
\hline \multirow[b]{2}{*}{ Ability tests } & Greek & 2.65 & \multirow[t]{2}{*}{.66} \\
\hline & Foreign/Subsidiary & 2 & \\
\hline \multirow{2}{*}{ Motivational inventories } & Greek & 2.79 & \multirow{2}{*}{.28} \\
\hline & Foreign/Subsidiary & 2.5 & \\
\hline \multirow[b]{2}{*}{ Personality inventories } & Greek & 3.20 & \multirow{2}{*}{.80} \\
\hline & Foreign/Subsidiary & 2.25 & \\
\hline \multirow{2}{*}{ Integrity tests } & Greek & 2.65 & \multirow{2}{*}{-.08} \\
\hline & Foreign/Subsidiary & 2.75 & \\
\hline \multirow{2}{*}{ Interviews } & Greek & 6.41 & \multirow{2}{*}{-.89} \\
\hline & Foreign/Subsidiary & 7 & \\
\hline \multirow{2}{*}{ Assessment centers } & Greek & 1.86 & \multirow{2}{*}{-.20} \\
\hline & Foreign/Subsidiary & 2 & \\
\hline \multirow{2}{*}{ Internet/ Social media } & Greek & 2.10 & \multirow[t]{2}{*}{.47} \\
\hline & Foreign/Subsidiary & 1.75 & \\
\hline \multirow[b]{2}{*}{ Other } & Greek & 1.34 & \multirow{2}{*}{-2.64} \\
\hline & Foreign/Subsidiary & 3 & \\
\hline
\end{tabular}




\section{Recruitment and Selection practices VS Hotel Size (H1b)}

Concerning the size of hotel, in number of employees, literature claims that the bigger the establishment, the more likely is to implement a wider range of recruitment and selection practices so as to spot, attract and hire, these employees having the necessary skills and attitudes to perform well and offer a high level of service. However, in Greece and in hotel industry in particular, the majority of firms are small or medium in size, employing less than 250 employees. Thus, since our sample was quite skewed towards hotels employing less than 250 employees, two categories where created for the purposes of H1b testing (less than 200, and greater than 200). From the analysis of data, it comes out that (Table 6), means and standard deviations of recruiting practices are non-significant, apart from the case of job rotation.

Table 6

Recruitment Practices VS Hotel Size

\begin{tabular}{|c|c|c|c|}
\hline Recruitment Practices & Size (number of employees) & Mean & t-test $(\mathrm{a}=5 \%)$ \\
\hline \multirow{2}{*}{ Promotion } & $<200$ & 4.043478 & \multirow{2}{*}{-0.7017} \\
\hline & $>200$ & 4.5 & \\
\hline \multirow{2}{*}{ Transfer } & $<200$ & 3.478261 & \multirow{2}{*}{-1.1853} \\
\hline & $>200$ & 4.3 & \\
\hline \multirow{2}{*}{ Job Rotation } & $<200$ & 3.608696 & \multirow{2}{*}{$-2.4427^{*}$} \\
\hline & $>200$ & 4.9 & \\
\hline \multirow{2}{*}{ Agencies } & $<200$ & 2.478261 & \multirow{2}{*}{-0.1690} \\
\hline & $>200$ & 2.6 & \\
\hline \multirow{2}{*}{ Liaison with universities } & $<200$ & 3.304348 & \multirow{2}{*}{-0.5121} \\
\hline & $>200$ & 3.7 & \\
\hline \multirow{2}{*}{ Job fairs* } & $<200$ & 2.521739 & \multirow{2}{*}{0.2078} \\
\hline & $>200$ & 2.4 & \\
\hline \multirow{2}{*}{ Walk ins, unsolicited resumes } & $<200$ & 3.695652 & \multirow{2}{*}{0.4196} \\
\hline & $>200$ & 3.4 & \\
\hline \multirow{2}{*}{ Employee referrals } & $<200$ & 4.173913 & \multirow[t]{2}{*}{-0.4301} \\
\hline & $>200$ & 4.4 & \\
\hline \multirow{2}{*}{ Company website } & $<200$ & 3.217391 & \multirow[t]{2}{*}{-0.5441} \\
\hline & $>200$ & 3.7 & \\
\hline \multirow{2}{*}{ Internet/Social Media } & $<200$ & 2.782609 & \multirow[t]{2}{*}{-0.8885} \\
\hline & $>200$ & 3.4 & \\
\hline \multirow{2}{*}{ Print Advertisement } & $<200$ & 3.478261 & \multirow{2}{*}{1.4860} \\
\hline & $>200$ & 2.3 & \\
\hline \multirow{2}{*}{ Internal job posting } & $<200$ & 3.782609 & \multirow{2}{*}{-1.7765} \\
\hline & $>200$ & 5.1 & \\
\hline \multirow{2}{*}{ Other } & $<200$ & 1.826087 & \multirow{2}{*}{0.5365} \\
\hline & $>200$ & 1.5 & \\
\hline
\end{tabular}

Regarding for selection methods, application forms and interviews are almost always used by large hotels-mean 6.9- and very often by hotels employing less than 200 employees- mean 5.2). Resume screening, reference checks are very often used by both size of hotels, while the 
selection methods mix remains the same (Table 7). In turn our null hypothesis of equality is accepted and thus $\mathrm{H} 1 \mathrm{~b}$ is rejected, suggesting no significant difference between small and large hotels.

Table 7

Selection Practices VS Size of Establishments

\begin{tabular}{|c|c|c|c|}
\hline Selection Practices & Size (number of employees) & Mean & t-test $(\mathrm{a}=5 \%)$ \\
\hline \multirow{2}{*}{ Reference checks } & $<200$ & 5.782609 & \multirow{2}{*}{-0.1995} \\
\hline & $>200$ & 5.9 & \\
\hline \multirow{2}{*}{ Application forms } & $<200$ & 5.173913 & \multirow{2}{*}{$-2.7649 *$} \\
\hline & $>200$ & 6.9 & \\
\hline \multirow{2}{*}{ Resume screening } & $<200$ & 5.521739 & \multirow{2}{*}{-1.9201} \\
\hline & $>200$ & 6.6 & \\
\hline \multirow{2}{*}{ Knowledge Tests } & $<200$ & 3.434783 & \multirow{2}{*}{-0.5236} \\
\hline & $>200$ & 3.9 & \\
\hline \multirow{2}{*}{ Performance/Work sample tests } & $<200$ & 3.826087 & \multirow[t]{2}{*}{0.2772} \\
\hline & $>200$ & 3.6 & \\
\hline \multirow{2}{*}{ Ability tests } & $<200$ & 2.565217 & \multirow{2}{*}{-0.0496} \\
\hline & $>200$ & 2.6 & \\
\hline \multirow{2}{*}{ Motivational inventories } & $<200$ & 2.521739 & \multirow[t]{2}{*}{-1.1016} \\
\hline & $>200$ & 3.3 & \\
\hline \multirow{2}{*}{ Personality inventories } & $<200$ & 2.782609 & \multirow{2}{*}{-1.2230} \\
\hline & $>200$ & 3.8 & \\
\hline \multirow{2}{*}{ Integrity tests } & $<200$ & 2.478261 & \multirow{2}{*}{-0.8186} \\
\hline & $>200$ & 3.1 & \\
\hline \multirow{2}{*}{ Interviews } & $<200$ & 6.304348 & \multirow{2}{*}{-1.2942} \\
\hline & $>200$ & 6.9 & \\
\hline \multirow{2}{*}{ Assessment centers } & $<200$ & 1.826087 & \multirow{2}{*}{-0.3717} \\
\hline & $>200$ & 2 & \\
\hline \multirow{2}{*}{ Social media } & $<200$ & 2.086957 & \multirow{2}{*}{0.1653} \\
\hline & $>200$ & 2 & \\
\hline \multirow{2}{*}{ Other } & $<200$ & 1.478261 & \multirow{2}{*}{-0.4527} \\
\hline & $>200$ & 1.7 & \\
\hline
\end{tabular}

\section{Effectiveness of Recruitment and Selection Practices}

Referring now to how much effective recruitment and selection practices are evaluated by all HR managers, in Greek and foreign hotels, and regardless of star category and hotel size, it appears that the level of effectiveness is quite similar.

The recruitment methods considered to be more effective are: promotion, transfer, job rotation, employee referrals and job posting, without though any of them to be considered very much effective (mean 4.91 max in a 7 point Likert scale), (Table 8). 
Table 8

Effectiveness of Recruitment and Selection Practices (Rating)

\begin{tabular}{lllll}
\hline \multicolumn{1}{c}{ RECRUITMENT } & & & SELECTION & Mean \\
\cline { 1 - 2 } \cline { 5 - 5 } Practice & Mean & & Practice & 5.58 \\
Promotion & 4.91 & & Reference Checks & 4.79 \\
Transfer & 4.36 & & Application Forms & 5.27 \\
Job Rotation & 4.42 & & Resume Screening & 3.85 \\
Recruitment Agencies & 3.73 & & Knowledge Tests & 4.45 \\
Liaison with universities & 3.58 & & Performance/ Work Sample Tests & 3.67 \\
Job Fairs & 2.88 & & Ability Tests & 3.48 \\
Walk-ins, Unsolicited resumes & 3.42 & & Motivational Fit Inventories & 3.48 \\
Employee Referrals & 4.42 & & Personality Inventories & 3.45 \\
Internet (Company Website) & 3.82 & & Integrity Tests & 6.21 \\
Internet (Social Media) & 3.15 & & Interviews & 3.33 \\
Print Advertisement & 3.82 & & Assessment Centres & 2.73 \\
Internal Job Positing & 4.21 & Social Media & 2.21 \\
\hline Other & 3.00 & Other & \\
\hline
\end{tabular}

Selection methods seem to score higher (mean up to 6.21) in their effectiveness. The methods considered to be more effective are interviews, reference checks, application forms, resume screening and work sample (Table 8). Thus, it can be assumed that even recruitment methods score lower in effectiveness, selection methods work more effectively.

\section{Discussion}

The hotel HR practices mix of recruitment and selection examined in this study are not differentiated by size, class and ownership of hotel. In particular, the research findings reveal that the use of resume screening and recruitment interview is very high for both categories of hotels and irrespectively of hotel size and type of ownership. This finding is similar to other researchers' findings (Chan \& Kuok, 2011; Kapiki, 2012).

A major finding about $5^{*}$ and $4^{*}$ hotels is that, apart from formal application forms and resume screening as selection methods, there is high similarity in the use of recruitment and selection practices. An explanation for this might be that $4^{*}$ and $5^{*}$ hotels are looking for the same profile of employees, with similar skills and abilities, and consequently they apply similar practices to attract and hire them. Although not significant, an interesting finding to note is that there is a tendency for both $4^{*}$ and $5^{*}$ hotels to use interviews a lot, and for $5^{*}$ in particular to use reference checks and knowledge tests much more than $4^{*}$ hotels. This finding might be justified by the bigger size of $5^{*}$ hotels and by the fact that in Greece interviews and reference checks are preferred as considered to better predict employee performance (Nikolaou \& Judge, 2007).

Both Greek and foreign hotel firms, rarely use recruitment agencies as a method of recruiting. This may happen because this method is quite expensive and away from the Greek culture (Stavroulakis, 2009). In addition, as an expensive method, it is not preferable for an industry with high turnover rates, which needs to repeat the process often (Davidson \& Wang, 2011; Hoque, 2013).

Internal recruitment methods such as promotion and transfer of employees are more frequently used by foreign subsidiaries comparing to Greek hotels (the degree of use varies very substantially). This probably happens because they want to maintain already existing 
talent, or because they value more loyalty compared to expertise, or maybe because they prefer to train their already existing employees who are already familiar with their firm's culture (Aycan et al., 2000).

The high level of similarity of recruitment and selection practices used by Greek and foreign hotels, is an indication that foreign hotels are having a flexible IHRM orientation and are moving towards local isomorphism. The reason for this is probably the cultural and institutional context in Greece (host-country specific factors). With the second being too restrictive and the first too distinctive, MNEs want to avoid cultural myopia and becoming ineffective and thus, tend to use similar to local hotels practices (Aycan et al., 2000; Brewster \& Sutari, 2005; Chung, 2015; Myloni, 2002).

The little use of contemporary recruiting and selection methods by the hotel industry in Greece is a major finding of this research. This is compared to similar findings by other researchers (Cheng \& Brown, 1998; McGunnigle \& Jameson, 2000; Yang \& Cherry, 2008).

The low rating of recruitment methods effectiveness ( $\max 4.9$ in a 7-point scale) is not surprising for the hotel industry. This may be attributed to the high turn - over and to the reasons associated with it (low paid work, job insecurity, seasonality, not clear and promising career path, few opportunities for development, etc.), as well as to the fact that hotel human resource managers use mostly cost effective methods (i.e. internal methods) of recruitment which do not attract the most suitable of candidates (Young-Thelin \& Baluk, 2012).

\section{Conclusion}

The findings of this study suggest that for $5^{*}$ and $4^{*}$ hotels, star category, size, and ownership seem to bring overall no statistical significant differences in the choice and implementation of recruitment and selection practices. The use of old - fashioned and low cost methods is very typical of the (Greek) hotel industry. Regarding their effectiveness, internal recruitment methods seem to be more effective compared to external recruitment ones. Promotion, transfer, job rotation, employee referrals and job posting score higher of all recruitment methods in their effectiveness. Regarding the selection methods used, interviews, reference checks, application forms, resume screening and work sample seem to be more effective. Overall, selection methods work more effectively, compared to recruitment methods.

The study has both managerial and academic implications. From an academic point of view, it contributes to the literature of International HRM in hotel industry. It adds to the existing literature about HRM practices in Greece and especially recruitment and selection practices, but more importantly, it adds to the very limited research in the area of Greek hotel industry and HRM (Kapiki, 2012). From a managerial point of view, it enhances industry understanding, as it provides knowledge to both Greek and foreign managers/hotel owners who already have or they aim to have a hotel operating in Greece, indicating the most used and effective recruitment and selection methods.

The small sample number of foreign subsidiaries in the sample does not allow making meaningful comparisons between Greek and foreign subsidiaries and thus statistical significant results cannot be yielded. It should be though noted that the number of Greek owned hotels operating in Greece far outweigh the foreign ones. Due to that reason results cannot be generalised to the whole Greek hotel industry, as there might be several factors (such as seasonality, local business culture and prevailing labour market conditions) affecting the 
implementation and transfer of recruitment and selection practices in hotels (Daskin \& Tezer, 2012).

The increasing number of hotel MNE's all over the world calls for an investigation about the factors affecting transferability of HR practices (from mother companies to local subsidiaries). In particular, an inter-country research about the cultural factors affecting the HR practices might be of great interest to MNE's hotel enterprises. A comparison of the recruitment and selection practices applied, controlling for specific factors such as years of hotel operation, resort vs. business/city hotels and international vs. national/local chains, would also add to the literature. Research about the effect of recruitment and selection practices on the employment stability index and labour turnover index, would indicate the more efficient sources and methods of attracting and selecting employees. Metrics about HR practices and in particular about recruitment and selection (if used at all) in the Greek hotel industry would be an interesting piece of research.

\section{Acknowledgements}

This work has been partly supported by the University of Piraeus Research Center.

\section{References}

Altin, M., Koseoglu M. A., Xiaojuan, Y., \& Riasi, A. (2018). Performance measurement and management research in the hospitality and tourism industry, International Journal of Contemporary Hospitality Management, 30(2), 1172-1189.

Apospori, E., Nikandrou, I., Brewster, C., Papalexandris, N. (2008). HRM and organizational performance in northern and southern Europe. The International Journal of Human Resource Management, 19 (7), 1187-1207.

Armstrong, M. (2017). Armstrong's Handbook of Human Resource Management Practice. London: Kogan Page.

Aycan, Z., Kanungo, R. N., Mendonca, M., Y, K., Deller, J., Stahl, G., \& Khursid, A. (2000). Impact of culture on human resource management practices: A 10 - Country Comparison. Applied Psychology: An international Review, 49(1), 192221.

Bagri, S. C., Babu, S., \& Kukreti, M. (2010). Human resource practices in hotels: A study from the tourist state of Uttrakhand. Journal of Human Resources in Hospitality and Tourism, 9(3), 283-299.

Baum, T. (2007). Human resources in tourism: still waiting for change. Tourism Management, 28, 1383-1399.

Brewster, C., \& Ssutari, V. (2005). Global HRM: Aspects of a research agenda, Personnel Review, 34(1), $2-21$.

Broughton, A., Foley B., Ledermaier, S., \& Cox, A. (2013). The use of social media in the recruiting process. London: Acas.

Centinel, F., Yolal, M., \& Emeksiz, M. (2008). Human resources management in small - and medium - sized hotels in Turkey. Journal of Human Resources in Hospitality and Tourism, 10(4), 421-441.

Chan, S. H., \& Kuok, O. M. (2011). A study of human resources recruitment, selection and retention issues in the hospitality and tourism industry in Macau. Journal of Human Resources in Hospitality and Tourism, 10(4), 421-441. doi: $10.1080 / 15332845.2011 .588579$.

Chand, M., \& Katou, A. A. (2007). The impact of HRM practices on organisational performance in the Indian hotel industry. Employee Relations, 29(6), 576-594.

Chanda, A., Bansal, T., \& Chanda, R. (2010). Strategic integration of recruitment practices and its impact on performance in Indian enterprises. Research and Practice in Human Resource Management, 18(1), 1-15.

Cheng, A., \& Brown, A. (1998). HRM strategies and labour turnover in the hotel industry: A comparative study of Australia and Singapore. International Journal of Human Resource Management, 9(1), 136-154.

Chung, C. (2015). The Conceptualization of Global Integration and Local Responsiveness in International HRM Research: A Review and Directions for Future Research. Henley Business School, University of Reading, discussion paper number JHD2015-02.

Chytiri, A. P. (2015). Human resource management and organizational performance - reconsidering the relationship (Unpublished doctoral dissertation). Athens University of Economics and Business, Athens. 
Darvishmotevali, M., Arasli, H., \& Kilic, H. (2017). Effect of job insecurity on frontline employee's performance: Looking through the lens of psychological strains and leverages. International Journal of Contemporary Hospitality Management, 29(6), 1724-1744.

Daskin, M., \& Tezer, M. (2012). Organizational politics and turnover: An empirical research from hospitality industry. Tourism Original Scientific Paper, 60(3), 273-291.

Davidson, M. C. G., \& Wang, Y. (2011). Sustainable labour practises? Hotel human resource managers' views on turnover and skill shortages. Journal of Human Resources in Hospitality and Tourism, 10(3), 235-253.

Davidson, M. C. G., McPhail, R., \& Barry, S. (2011). Hospitality HRM: Past, present and the future. International Journal of Contemporary Hospitality Management, 23(4), 498-516.

Diaz de Rada, V., \& Dominguez-Alvarez, J. A. (2013). Response quality in self - administered questionnaires: A comparison between paper and web questionnaires. Social Science Computer Review, Sage, 32(2), 256-269.

Duncan, T., Scott, D. G., \& Baum, T. (2013). The motilities of hospitality work: An exploration of issues and debates. Annals of Tourism Research, 41(4), 1-19.

Easterby-Smith, M., Thorpe, R., Jackson, P., \& Lowe, A. (2008). Management Research, $3^{\text {rd }}$ Edition. NY: Sage Publication.

Eleftheriou, A., \& Robertson, I. (1999). A survey of management selection practices in Greece. International Journal of Selection and Assessment, 7(4), 203-208.

Enz, C. A. (2009). Human resource management: A troubling issue for the global hotel industry. Cornell Hospitality Quarterly, 50(4), 578-583.

Gonzalez, L., \& Rivares, L. (2017). Analysis of the impact of referral - based recruitment on job attitudes and turnover in temporary agency workers. Employee Relations, 40(1), 89-105.

Gravlee, C. C., Bernard, H. R., Maxwell, C. R., \& Jacobsohn, A. (2013). Mode effects in free - list elicitation: Comparing oral, written and web - based data collection. Social Science Computer Review, 31(1), 119-132.

Greek Tourism Organization (2017). Statistics and Insights. Retrieved from www.gnto.gov.gr (accessed 7/3/2018).

Guest, D. (2011). HRM and performance: Still searching for some answers. Human Resource Management Journal, 21(1), 312.

Hayslett, M. M., \& Wildemuth, B. M. (2004). Pixels or pencils? The relative effectiveness of Web - based versus paper surveys. Library and Information Science Research, 26, 73-93.

Hazra, S., \& Nemes, Z. (2013). Understanding of human resource management issues in the current hospitality industry. Journal of Contemporary Development and Management Studies, 2(1), 29-36.

Hoque, K. (1999). Human resource management and performance in the UK hotel industry. British Journal of Industrial Relations, 37(3), 419-43.

Hoque, K. (2013). Human resource management in the hotel industry, strategy, innovation and performance. London: Routledge Publishing, Taylor \& Francis Group.

Huselid, M. A. (1995). The impact of human resource management practices on turnover productivity and corporate financial performance. Academy of Management Journal, 38(3), 635-672.

Janes, P., \& Wisnom, M. (2010). Changes in tourism industry quality of work life practices. Journal of Tourism Insights, $1(1 / 13), 107-113$

Kapiki, S. (2012). Current and future trends in tourism and hospitality: The case of Greece. International Journal of Economic Practices and Theories, 2(1), 1-12.

Katou, A. A., \& Budhwar, P. S. (2012). The link between HR practices, psychological contract fulfilment and organizational performance: The case of the Greek services sector. Thunderbird International Business Review, 54(6), 793-809.

Katou, A. A. (2008). Human resource management and performance in the hospitality industry: methodological issues. International Journal of Tourism and Hospitality Systems, 1(1), 23-54.

Kusluvan, S., Kusluvan, Z., Iihan, I., \& Buyruk, L. (2010). The human dimension: A review of human resources management issues in the tourism and hospitality industry. Cornell Hospitality Quarterly, 51(2), 171-214.

Ladkin, A. (2011). Exploring tourism labour. Annals Tourism Research, 38(3), 1135-1155.

Lievens, F., Van Dam, K., \& Anderson, N. (2002). Recent trends and challenges in personnel selection. Personnel Review, $31(5), 580-601$

Lockyer, C., \& Scholarios, D. (2004). Selecting hotel staff: Why best practice dies not always work. International Journal of Contemporary Hospitality Management, 16(2), 125-135.

McGunnigle, P. J., \& Jameson, S. M. (2000). HRM in UK hotels: A focus on commitment. Employee Relations, 22(4), 403422. 
Mooney, S. K., Harris, C. H., \& Ryan, I. (2016). Long hospitality careers - a contradiction in terms? International Journal of Contemporary Hospitality Management, 28(11), 2589-2608.

Myloni, B. (2002). The transfer of human resource management practices within multinational companies in Greece (Unpublished doctoral dissertation). School of Management of University of Bradford, Bradford.

Myloni, B., Harzing, A-W., \& Mirza, H. (2004). Host country specific factors and the transfer of human resource management practices in multinational companies, International Journal of Manpower, 25(6), 518-534.

Myloni, B., Harzing, A. W., \& Mirza, H. (2003). Human resources management in Greece: Have the colours of culture faded away? International Journal of Cross Cultural Management, 4(1), 59-76.

Nieves, J., \& Quintana, A. (2016). Human resource practices and innovation in the hotel industry: the mediating role of human capital. Tourism and Hospitality Research, 18(1), 72-83. doi: 1467358415624137.

Nikolaou, I., \& Judge, T. A. (2007). Fairness reactions to personnel selection techniques in Greece: The role of core selfevaluations. International Journal of Selection and Assessment, 15(2), 206-219.

Noe, A. R., Hollenbeck, R. J., Gerhart, B., \& Wright, M. P. (2015). Human resource management: Gaining a competitive advantage, $9^{\text {th }}$ Edition. UK: McGraw Hill, Berkshire.

Panayotopoulou, L., Vakola, M., \& Galanaki, E. (2007). E-HR adoption and the role of HRM: Evidence from Greece. Personnel Review, 36(2), 277-294.

Panayotopouloy, L., Galanaki, E., \& Papalexandris, N. (2010). Adoption of electronic systems in HRM: Is national background of the firm relevant? New Technology, Work and Employment, 25(3), 253-269.

Papalexandris, N., \& Stavrou, E. (2004). Human resource management in the Southeastern Mediterranean corner of Europe: The Case of Italy, Greece and Cyprus. In C. Brewster, W. Mayrhofer, \& M. Morley, (Eds.), Human Resource Management in Europe: Evidence of Convergence? Burlington, MA: Elsevier Butterworth - Heinemann.

Paraskevas, A. J. (2000). Management selection practices in Greece: Are hospitality recruiters any different? International Journal of Hospitality Management, 19(3), 241-259.

Philippakos, J. (2009). A Comparison of hospitality resources practises in Greece and the United States: An analysis of human resources practises and potential effects on service quality. UNLV Theses/Dissertation/Professional Papers/Capstones, paper 560 .

Purcell, J., Kinnie, N., Hutchinson, S., Rayton, B., \& Swart, J. (2003). Understanding the people and performance link: Unlocking the black box. London: CIPD.

Rea, M. L., \& Parker, A. R. (2014). Designing and conducting survey research. San Francisco: Josey-Bass.

Roth, P. L., Bobko, P., Van Iddekinge, C. H., \& Thatcher, J. B. (2016). Social media in employee selection-related decisions: a realistic agenda for uncharted territory, Journal of Management, 42(1), 269-298.

Solnet, D. Kralj, A., \& Baum, T. (2015). 360 degrees of pressure the changing role of the HR professional in the hospitality industry. Journal of Hospitality and Tourism Research, 39 (2), 271-292.

Stavrou-Costea, E., \& Papalexandris, N. (2015). Mediterranean HRM - key trends and challenges. In M. Dickmann, C. Brewster, \& P. Sparrow (Eds.), International HRM: Contemporary issues in Europe, $3^{\text {rd }}$ edition. Edward Elgar Publishers.

Stavrou, E., Brewster, C., \& Charalambous, C. (2010). Human resource management and firm performance in Europe through the lens of business systems: Best fit, best practice or both? International Journal of Human Resource Management, 21(7), 933-962.

Stavroulakis, D. (2009). HRM practices in view of internationalization: Evidence from business in Greece. MIBES Transactions, 3(1), 147-156.

Stone, D., Deadrick, D., Lucaszewski, K., \& Johnson, R. (2015). The influence of technology on the future of human resource management. Human Resource Management Review, 25, 216-231.

Suh, E, West, J. J., \& Shin, J. (2012). Important competency for managers in the hospitality industry. Journal of Hospitality, Leisure, Sport and Tourism Education, 11, 101-112.

Taylor, S. (2014). Resourcing and talent management, $6^{\text {th }}$ edition. London: CIPD.

Torrington, D., Hall, L., Taylor, St., \& Atkinson, C. (2017). Human resource management, $10^{\text {th }}$ edition. United Kingdom: Pearson Education Ltd.

Ubeda-Garcia, M., Claver-Cortes, E., Marco-Lajara, M., \& Zaragoza-Saez, P. (2017). Human resource flexibility and performance in the hotel industry: The role of organizational ambidexterity. Personnel Review, 46(4), 824-846. 
Walsh, K., Enz, C. A., \& Siguaw, J. A. (2007). Innovations in hospitality human resources: Cases form the U.S. lodging industry. Retrieved from Cornell University, SHA School Site: https://scholarship.sha.cornell.edu/articles/864/ (accessed 3/3/2018).

World Travel and Tourism Council (2017). Travel and tourism economic impact: Greece. Retrieved from https://www.wttc.org/-/media/files/reports/economic-impact-research/countries-2017/greece2017.pdf (accessed 7/3/2018).

Wright, K. B. (2005). Researching Internet-based populations: Advantages and disadvantages of online survey research, Online Questionnaire Authoring Software Packages and Web Survey Services. Journal of Computer-Mediated Communication, 10(3). Retrieved from https://doi.org/10.1111/j.1083-6101.2005.tb00259.x

Yang, H. O., \& Cherry, N. (2008). Human resource management challenges in the hotel industry in Taiwan. Asia Pacific Journal of Tourism Research, 13(4), 399-410.

Young-Thelin, L., \& Boluk, K. (2012). A case study of human resource practices in small hotels in Sweden. Journal of Human Resources in Hospitality and Tourism, 11(4), 327-353. 